\title{
МОБІЛЬНІ ТЕХНОЛОГІЇ ДЛЯ МОНІТОРИНГУ ПОКАЗНИКІВ СТАНУ ЗДОРОВ'я
}

\author{
${ }^{1}$ Львівський національний медичний університет імені Данила Галицького, м. Львів, Україна \\ ${ }^{2}$ Національний університет «Києво-Могилянська академія», м. Київ, Україна \\ ${ }^{3}$ Національний університет «Львівська політехніка», м. Львів, Україна
}

\begin{abstract}
Своєчасна діагностика стану організму людини у режимі віддаленого доступу без відвідування спеціалізованих медичних закладів, автоматизований моніторинг стану здоров'я людини на всіх етапах лікування, реабілітації та профрілактики захворювань, отримання професійних медичних консультацій за допомогою спеціальних web-порталів $€$ актуальними питаннями охорони здоров'я, розв'язання яких можливе лише при використанні сучасних інформаційних технологій.

Мета: проаналізувати існуючі системи та розробити нові методи та мобільні програмні засоби, що дозволять оперативно визначати, аналізувати та контролювати психоемоційний та фрізичний стан здоров'я людини.

Матеріали і методи. Розроблено концепцію створення модульної багатопараметричної мультифункціональної мобільної системи із сервісною платсрормою, яка призначена для моніторингу, тривалого спостереження та контролю основних психофізіологічних показників, що характеризують стан організму людини.

Результати. Експериментальні дослідження роботи основних модулів системи були практично проведені під час аналізу частоти серцевого ритму в 5 діапазонах за допомогою медичного гаджету MioFuse та розробленого мобільного додатку MioGo.

Висновки. Використання інформаційних та мобільних технологій дозволяє організувати роботу з системою у режимі віддаленого доступу, реалізувати персоналізований підхід до пацієнтів із відображенням даних на екрані смарторона користувача.
\end{abstract}

КЛЮчОВІ СЛОВА: медичні мобільні програмні засоби; AS4u; медичні гаджети; моніторинг.

Одним із найактуальніших питань системи охорони здоров'я $є$ пошук нових підходів до відновного лікування на всіх етапах реабілітації та оздоровлення різних груп населення. Сучасний стан розвитку інформаційних технологій відкриває нові можливості у цьому напрямку, дозволяє реалізувати персоналізований підхід, оперативність, організувати моніторинг показників здоров'я у режимі віддаленого доступу з використанням медичних гаджетів та мобільних додатків (m-health).

Сьогодні розробники пропонують різноманітні медичні гаджети для вимірювання окремих показників: пульсу (Instant Heart Rate, Runtastic Heart Rate Monitor), артеріального тиску (Blood Pressure Monitor), рівня стресу (Stress Check) та ін. Система Soarian Clinical дозволяє у режимі віддаленого доступу проводити моніторинг стану здоров'я пацієнта та його кардіостимулятора, а система давачів Visi Mobile надає можливість вчасно зафріксувати погіршення стану пацієнта та з'єднати його 3 лікарем для консультації. Мобільний додаток iCare Health Monitor дозволяє проводити швидку перевірку зорової та слухової підсистем організму людини, визначати рівень артеріального

(с) Н.В. Дорош, К.І. Ільканич, О.І. Дорош, І.Р. Бойко, 2017 тиску та частоти серцевих скорочень, ємність легень та швидкість дихання, насичення крові киснем, а також проводити психологічне тестування. Платорорма Apple Health-сервіс може збирати показники серцевого ритму, рівень глюкози, кількість калорій, дані про режим сну через вбудований інтерфейс. Недоліком таких засобів $€$ відсутність можливості профресійного аналізу отриманих даних [1-3].

Мета дослідження: проаналізувати існуючі системи та розробити нові методи та мобільні програмні засоби, а також відповідні інформативно комунікаційні технології, що дозволять оперативно визначати, аналізувати та контролювати психоемоційний та фрізичний стан здоров'я людей на різних етапах лікування та реабілітації, своєчасно надавати їм необхідну допомогу та проводити профрілактичні заходи для зміцнення їх здоров'я.

Матеріали і методи. Для реалізації поставленої мети розроблено концепцію створення модульної багатопараметричної мультифункціональної мобільної системи із сервісною платфрормою, яка призначена для моніторингу, тривалого спостереження та контролю основних психофрізіологічних показників, що характеризують стан організму 
людини. Основними модулями системи є модуль реєстрації (сенсорна електроніка, медичні гаджети або портативні прилади), модуль експрес-аналізу показників, модулі комплексного аналізу, прогнозування та орормування корегуючих програм для медичної або фрізичної реабілітації (рис. 1). У системі реалізовано адаптивний підхід із поглибленням рівня професійного аналізу, а також ланка зворотного зв'язку для оптимізації програм корегування. Для підвищення рівня достовірності отриманих результатів у системі передбачено проведення порівняльного аналізу вербальних та фрізіологічних показників. Вербальні показники можна отримати за допомогою опитування та тестування респондентів, а для реєстрації фрізіологічних параметрів можна застосовувати медичні гаджети та мобільні додатки. Сервісна платорорма забезпечує інтерфейсні функції, обробку та збереження даних та результатів аналізу [4]. Система має клієнт-серверну архітектуру та реалізована для OC Android i може бути адаптована для інших ОС (рис. 1).

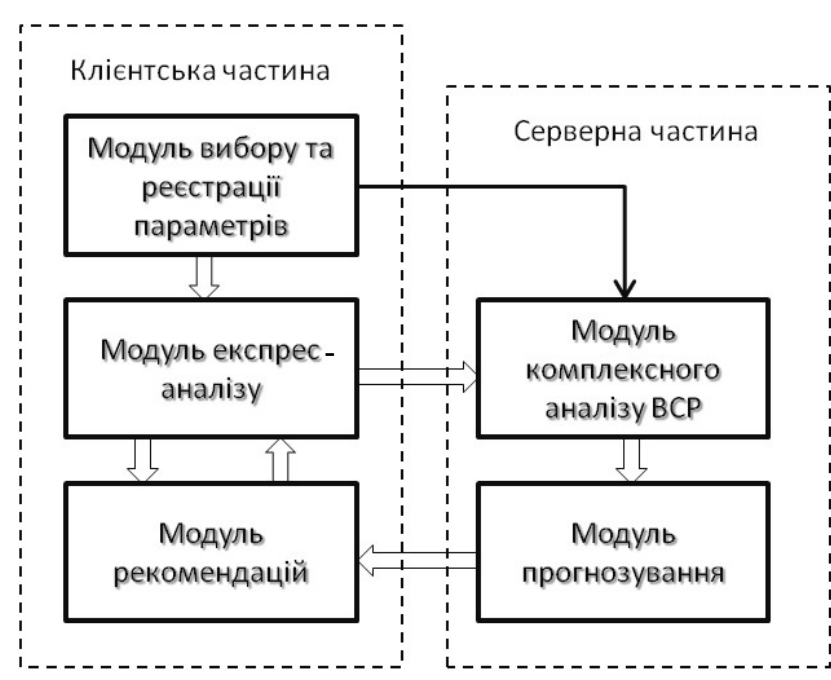

Рuc. 1. Структурна організація системи.

Результати дослідження та їх обговорення. Експериментальні дослідження роботи основних модулів системи були практично проведені під час аналізу частоти серцевого ритму в 5 діапазонах за допомогою медичного гаджету MioFuse та мобільного додатку MioGo [4]. На рисунку 2 показано відображення результатів тривалого спостереження пульсу (10 годин) на екрані смартфона, а на рисунку 3 - результати аналізу кардіоінтервалів за допомогою спеціально розробленого програмного забезпечення.

Система дозволяє також проводити персоналізований експрес-аналіз показників стану здоров'я користувачів у режимі віддаленого доступу, визначати групи ризику та рекомендувати респондентам реабілітаційні або санаторно-курортні заклади для стабілізації та покращення їх здоров'я, інорормація про які отримується зі спеціально розробленого web-порталу [5].

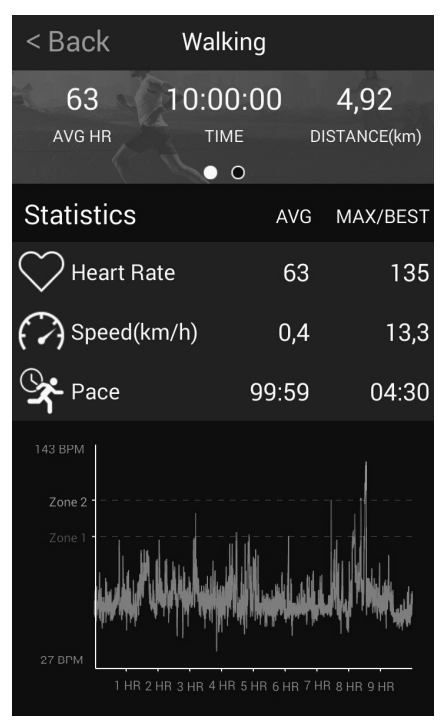

Puc. 2. Реєстрація частоти серцевих скорочень.

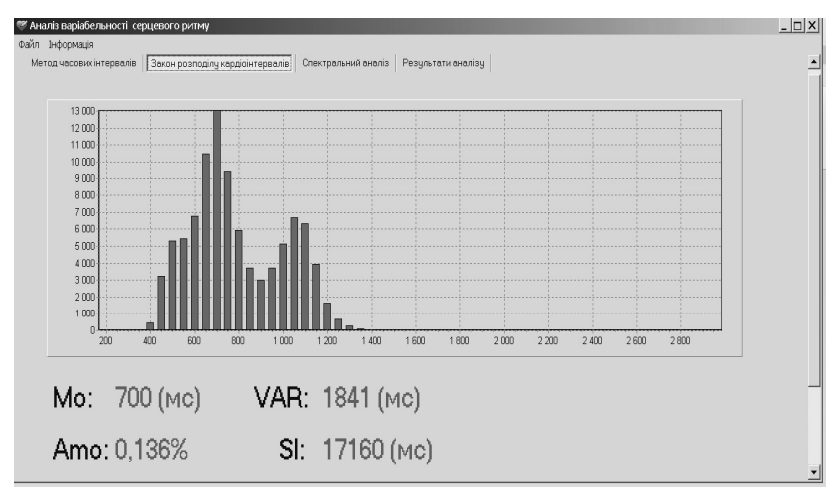

Рис. 3. Результати розподілу кардіоінтервалів.

Для розробки web-порталу використано комп'ютерно-інформаційну систему автоматизованого проектування web-сайтів AS4u. Вона дозволяє проводити автоматизоване опрацювання різноманітної символьної, графрічної і відеоінформації та обробляти інформацію в режимі on-line.

\section{Висновки}

Теоретичні та експериментальні дослідження запропонованої модульної багатопараметричної мультифункціональної мобільної системи із сервісною платформою показали, що вона $€$ ефрективним засобом для моніторингу, тривалого спостереження та контролю основних показників, що характеризують стан організму людини. Використання мобільних технологій дозволяє організувати роботу з системою у режимі віддаленого доступу, реалізувати персоналізований підхід до пацієнтів із відображенням даних на екрані смартфона користувача. Розроблено спеціальний webпортал із модулем експрес-аналізу стану здоров'я за допомогою медичних гаджетів та мобільних додатків, що дає можливість покращити доступність користувачів до потрібних їм закладів реабілітації та оздоровлення.

Перспективи подальших досліджень полягають у вивченні ефективності запропонованих інновацій. 


\section{Список літератури}

1. Мінцер О. П. Особливості діагностики стану здоров'я пацієнта з позиції мобільної медицини. Постановка проблеми [Текст] / О. П. Мінцер, Я. О. Шевченко // Медична інорорматика та інженерія. - 2016. - № 4 - С. 31-36.

2. Персонализированная медицина: современное состояние и перспективы [Текст] / И. И. Дедов, А. Н. Тюльпаков,

В. П. Чехонин [и др.] // Вестник РАМН. - 2012. - № 12. - С. 4-10.

3. Абдуллаев В. Г. Мобильные приложения для здоровья [Текст] / В. Г. Абдуллаев, Т. К. Аскеров, И. В. Чуба // Радиоэлектроника и инорорматика. - 2014. - Т. 1, № 64.

4. Дорош О. І. Медичний мобільний пристрій на базі OC ANDROID / O. І. Дорош // Вісник Національного технічного університету «Харківський політехнічний інститут». Збірник наукових праць. Серія: Інфрорматика та моделювання. Харків : НТУ «ХП|». - 2015. - № 32 (1141). - С. 60-68.

5. Інформаційна система на основі технології AS4u для організації оздоровлення та реабілітації з модулем експресаналізу стану здоров'я / О. В. Бойко, Н.В.Дорош, К. І. Ільканич, О. І. Дорош // Інфрорматика. Культура. Техніка : матеріали V Українсько-німецької конференції, 22-26 травня 2017 р. - Одеса. - С. 51-52.

\section{References}

1. Mintser, O.P., \& Shevchenko, Ya.O. (2016). Osoblyvosti diahnostyky stanu zdorovia patsiienta z pozytsii mobilnoi medytsyny. Postanovka problemy [Peculiarities of diagnostics of the patient's health status on the positions of mobile medicine. Problem statement]. Medychna informatyka ta inzheneriia - Medical Informatics and Engineering, 4, 31-36 [in Ukrainian].

2. Dedov, I.I., Tulpakov, A.N, \& Chekhonin, V.P (2012). Personalizirovannaya meditsina: sovremennoe sostoyanie $i$ perspektivy [Personalized medicine: the current state and prospects]. Vestnik RAMN - Journal of RAMN, 12, 4-10.

3. Abdulaev, V.G., Askerov, T.K, \& Chuba, I.V (2014). Mobilnye prilozheniya dlya zdorovya [Mobile applications for health]. Radioelektronika i informatika - Radioelectronics and Informatics, 1 (64) [in Russian].

4. Dorosh, O.I. (2015). Medychnyi mobilnyi prystrii na bazi OS Android [Medical mobile device on the base of OS Android]. Visnyk Natsionalnoho tekhnichnoho universytetu «Kharkivskyi politekhnichnyi instytut». Zbirnyk naukovykh prats. Seriia: Informatyka ta modeliuvannia - Journal of the National Technical University «Kharkiv Polytechnic Institute». Collection of Scientific Works. Series: Computer Science and Modeling. Kharkiv [in Ukrainian].

5. Boiko, O.V., Dorosh, N.V., Ilkanych, K.I., \& Dorosh, O.I. (2017). Informatsiina systema na bazi tekhnolohii AS4U dlia orhanizatsii ozdorovlennia ta reabilitatsii z modulem ekspres-analizu stanu zdorovia [Information system based on the technology AS4U for the organization of health and rehabilitation with the module of express analysis of health]. Materialy V Ukrainsko-nimetskoi konferentsii, Informatyka. Kultura. Tekhnika - Materials of the V Ukrainian-German Conference, Informatics. Culture. Machinery. Odesa [in Ukrainian].

\section{МОБИЛЬНЫЕ ТЕХНОЛОГИИ ДЛЯ МОНИТОРИНГА ПОКАЗАТЕЛЕЙ СОСТОЯНИЯ ЗДОРОВЬЯ}

Н.В. Дорош', Е.И. Ильканич ${ }^{1}$ О.И. Дорош², И.Р. Бойко ${ }^{3}$

1Львовский национальный медицинский университет имени Данила Галицкого, г. Львов, Украина

${ }^{2}$ Национальный университет «Киево-Могилянская академия», г. Киев, Украина

зНациональный университет «Львовская политехника», г. Львов, Украина

Своевременная диагностика состояния организма человека в режиме удаленного доступа без посещения специализированных медицинских учреждений, автоматизированный мониторинг состояния здоровья человека на всех этапах лечения, реабилитации и профилактики заболеваний, получение профрессиональных медицинских консультаций с помощью специальных web-порталов есть актуальными вопросами здравоохранения, решение которых возможно только при использовании современных информационных технологий.

Цель: проанализировать существующие системы и разработать новые методы и мобильные программные средства, которые позволят оперативно определять, анализировать и контролировать психоэмоциональное и оризическое состояние здоровья человека.

Материалы и методы. Разработана концепция создания модульной многопараметрической мультифункциональной мобильной системы с сервисной платформой, которая предназначена для мониторинга, длительного наблюдения и контроля основных психофизиологических показателей, характеризующих состояние организма человека.

Результаты. Экспериментальные исследования работы основных модулей системы были практически проведенные при анализе частоты сердечного ритма в 5 диапазонах с помощью медицинского гаджета MioFuse и разработанного мобильного приложения MioGo [3].

Выводы. Использование информационных и мобильных технологий позволяет организовать работу с системой в режиме удаленного доступа, реализовать персонализированный подход к пациентам с отображением данных на экране смартфона пользователя.

КЛЮЧЕВЫЕ СЛОВА: медицинские мобильные программные средства; AS4u; медицинские гаджеты; мониторинг. 


\section{MOBILE TECHNOLOGIES FOR MONITORING OF HEALTH STATUS INDICATORS}

N.V. Dorosh ${ }^{1}$, K.I. Ilkanych ${ }^{1}$, O.I. Dorosh, ${ }^{2}$ I.R. Boiko ${ }^{3}$

${ }^{1}$ Lviv Danylo Halytskyi National Medical University

${ }^{2}$ National University «Kyiv-Mohyla Academy»

${ }^{3}$ Lviv Polytechnic National University

Early diagnosis of the human body in the mode of remote access without visiting specialized medical institutions, automated monitoring of human health at all stages of treatment, rehabilitation and prevention of diseases, obtaining professional medical consultations through the use of special WEB-portals are topical issues of health care, the solution of which is possible only with the use of modern information technologies.

Purpose: analysis of existing systems and developing of new methods and mobile software tools, which will allow quickly identifying, analyzing and controlling the psycho-emotional and physical health of a person.

Materials and Methods. The concept of the creation of a modular multi-parameter multifunctional mobile system with a service platform, designed for monitoring, long-term observation and control of the basic psychophysiological indicators characterizing the state of the human organism, was developed.

Results. Experimental studies of the work of the main modules of the system were practically carried out during the analysis of heart rate in 5 ranges with the help of the MioFuse medical gadget and developed mobile application MioGo [3]

Conclusions. The use of information and mobile technologies allows organizing the work with the system in the remote access mode, realization of personalized approach to patients with the observation of data on the screen of the user's smartphone.

KEY WORDS: medical mobile software; AS4u; medical gadgets; monitoring.

Рукопис надійшов до редакції 19.09.2017 p.

\section{Відомості про авторів:}

Дорош Наталія Володимирівна - кандидат технічних наук, доцент кафедри «Медична інформатика» Львівського національного медичного університету імені Данила Галицького; тел. +38(032)276-78-08.

Ільканич Катерина Іванівна - кандидат технічних наук, старший викладач кафедри «Медична інформатика» Львівського національного медичного університету імені Данила Галицького; тел. +38(0382)276-78-08.

Дорош Олег Ігорович - старший викладач касредри мережних технологій Національного університету «КиєвоМогилянська академія»; тел. +38(096)910-42-23.

Бойко Іван Романович - студент Національного університету «Львівська політехніка»; тел. +38(097)314-70-64. 